\title{
Disputas Comerciaîs e Magnanimidade: Um Estudo do Mecanismo de Solução de Controvérsias da Organização Mundial de Comércio à Luz da Teoria dos Movimentos*
}

\section{Cristiane de Andrade Lucena Carneiro**}

Por que disputas comerciais no âmbito da Organização Mundial de Comércio (OMC) são decididas predominantemente de forma amigável, não obstante a existência de um sofisticado mecanismo quasi-adjudicatório para a resolução dessas controvérsias? Como explicar a preferência da parte que inicia uma disputa pela solução amigá-

\footnotetext{
* Artigo recebido em setembro de 2007 e aceito para publicação em julho de 2008. Artigo originalmente escrito em inglês e traduzido pela própria autora. A autora agradece as sugestões e comentários do professor Steven Brams, assim como de Jeffrey Dunoff, Amâncio de Oliveira e Allan Stam.

** Doutora em Ciência Política pela Universidade de Nova Iorque e pesquisadora do Centro de Estudos das Negociações Internacionais (Caeni) da Universidade de São Paulo (USP). E-mail: cristiane. lucena@caeni.com.br.
}

CONTEXTO INTERNACIONAL Rio de Janeiro, vol. 30, nº 3, setembro/dezembro 2008, p. 615-654. 
vel, quando se sabe que a OMC decide $64 \%$ dos casos a favor do iniciante, em média?

Este artigo analisa padrões de solução de controvérsias no sistema do Acordo Geral sobre Tarifas e Comércio (em inglês, General Agreement on Tariffs and Trade (GATT)) e da OMC por meio da teoria dos movimentos (BRAMS, 1994), e estuda as opções estratégicas disponíveis para as partes, perante o Mecanismo de Solução de Controvérsias (MSC), após a incorporação das reformas institucionais advindas da Rodada Uruguai de negociações de liberalização comercial (1986-1993).

Propõe-se que, no sistema GATT/OMC, a parte que inicia uma disputa comercial age de forma magnânima. Essa ação é racional do ponto de vista do iniciante porque magnanimidade proporciona mais oportunidades para uma solução amigável, do ponto de vista da defesa, o que no final beneficia ambas as partes. Este comportamento não é bem explicado pelos conceitos de equilíbrio míope da teoria dos jogos tradicional. Em contrapartida, a teoria dos movimentos (em inglês, theory of moves (TOM)) incorpora o raciocínio não-míope a seu modelo de tomada de decisões.

Brams (1994) utilizou a TOM para estudar vários conflitos distintos: a crise dos mísseis cubanos, a campanha de bombardeios no Vietnã, a crise dos reféns norte-americanos no Irã e várias histórias bíblicas. As negociações sobre liberalização no setor de agricultura durante a Rodada Uruguai também foram objeto de análise sob o prisma da teoria dos movimentos. ${ }^{1}$

$\mathrm{O}$ artigo encontra-se organizado da seguinte forma: primeiramente, faço uma retrospectiva das disputas comerciais decididas no âmbito da OMC, de forma amigável e litigiosa. Em um segundo momento, discuto hipóteses baseadas na teoria dos jogos tradicional, no que tange ao resultado das disputas levadas à OMC, a fim de mostrar as limitações desta teoria quando se trata de explicar o quadro empírico. 
Disputas Comerciais e Magnanimidade: Um

Estudo do Mecanismo de Solução...

A terceira parte faz uma exposição da teoria dos movimentos, com ênfase no Jogo de Magnanimidade (BRAMS, 1994). Por fim, exponho o recorde de solução de controvérsias no âmbito da OMC, à luz do Jogo de Magnanimidade.

A análise explica a racionalidade dos jogadores quando estes agem de forma não-míope e buscam o segundo melhor resultado no jogo. Três estudos de caso ilustram as características de disputas comerciais em que: (i) a solução amigável advém do comportamento magnânimo; (ii) a solução amigável ocorre a despeito do comportamento magnânimo; (iii) não ha solução amigável. Esses três resultados exaurem o recorde empírico das disputas na OMC.

\section{Panorama das Disputas Comerciais na OMC}

De janeiro de 1995 a janeiro de 2007, 356 disputas comerciais foram protocoladas na OMC (LEITNER; LESTER, 2007). Dado que este artigo se propõe a explicar o resultado de litígios na OMC, em seguida defino os dois resultados possíveis em uma disputa: escalada da disputa e solução amigável. A escalada resulta quando uma ou ambas as partes escolhem não cooperar. A ausência de cooperação define-se pela decisão de rejeitar um acerto com relação à barreira comercial objeto da disputa. A solução amigável ocorre quando ambas as partes optam por aceitar uma acomodação com relação à barreira comercial em questão e, desta forma, chegam a um resultado que é mutuamente aceitável.

Neste artigo, parto do pressuposto de que cooperação e não-cooperação são estratégias circunscritas às opções disponíveis no âmbito do regime adjudicatório da OMC. Na ausência deste pressuposto, os incentivos que influenciariam as escolhas dos jogadores seriam quase infinitos. Em realidade, os negociadores internacionais navegam por teias complexas de incentivos e recompensas. ${ }^{2}$ Como o Mecanismo 
de Solução de Controvérsias (MSC) possui duas instâncias decisórias, soluções amigáveis podem ocorrer em dois momentos distintos: (i) antes da decisão em primeira instância e (ii) depois da decisão em primeira instância, mas antes da decisão final do recurso. ${ }^{3}$ Com base nos dados mais recentes (LEITNER; LESTER, 2007), dos 356 casos protocolados desde 1995, 336 são objeto de estudo neste projeto. Os vinte casos protocolados em 2006 foram excluídos, porque seria impossível antecipar os desdobramentos destas disputas comerciais, tendo em vista o cronograma previsto no MSC. A Tabela 1 classifica os 336 casos de acordo com o resultado dos mesmos nas instâncias decisórias.

\section{Tabela 1}

Solução Amigável e Disputas na OMC (De Janeiro de 1995 a Janeiro de 2007)

\begin{tabular}{lcccc}
\hline Regime Jurídico & $\begin{array}{c}\text { Total de } \\
\text { Disputas }\end{array}$ & $\begin{array}{c}\text { Solução } \\
\text { Amigável } \\
\mathbf{1}^{\mathbf{a}} \text { instância }\end{array}$ & $\begin{array}{c}\text { Solução } \\
\text { Amigável } \\
\mathbf{2}^{\mathbf{a}} \text { instância }\end{array}$ & $\begin{array}{c}\text { Total de } \\
\text { Soluções } \\
\text { Amigáveis }\end{array}$ \\
\hline GATT & 207 & 119 & N/A* $^{*}$ & 119 \\
$(1948$ a 1989) & 336 & $(57 \%)$ & & $(57 \%)$ \\
OMC & & $(69 \%)$ & $(11 \%)$ & 269 \\
(jan. 1995 a jan. 2007) & & & & $(80 \%)$ \\
\hline
\end{tabular}

Fontes: Leitner e Lester (2007) e Hudec (1993).

${ }^{*} \mathrm{~N} / \mathrm{A}=$ não se aplica.

Dos 336 casos, 231 não culminaram com uma decisão jurídica vinculante na primeira instância; em outras palavras, não houve decisão do painel de peritos confirmada na instância competente. Esses casos constituem a categoria de solução amigável, na terminologia aqui adotada. Na mesma categoria, são incluídos os 38 casos em que houve uma decisão do painel de peritos, mas essa decisão não foi objeto de recurso para o órgão de apelação. ${ }^{4}$

Como pode ser observado na Tabela 1 , o número total de disputas objeto de solução amigável chega a 269 (80\%). É surpreendente que 


\section{Disputas Comerciais e Magnanimidade: Um Estudo do Mecanismo de Solução...}

este percentual seja muito superior ao percentual de casos solucionados amigavelmente durante os anos do GATT, quando o painel de peritos proferiu decisões em 88 dos 207 casos protocolados entre 1948 e 1989, o que se traduz em um percentual de solução amigável equivalente a $57 \%$. A expectativa seria contrária: tendo em vista o alto grau de institucionalização trazido pela Rodada Uruguai e, concomitantemente, o reforço dos mecanismos de enforcement, é surpreendente e paradoxal que disputas comerciais estejam encontrando solução amigável em maior número no pós-1995 (JACKSON, 2000; STEGER, 2004).

Neste artigo, eu confronto esse padrão de soluções amigáveis e explico a opção estratégica da parte que propõe a disputa, a despeito da evidência de que, no GATT/OMC, a parte proponente quase sempre é beneficiada na decisão final. ${ }^{5}$ A teoria dos jogos tradicional vê este cenário como um dilema do prisioneiro, em que as duas partes podem se beneficiar com uma solução amigável, evitando os custos associados ao processo adjudicatório no âmbito da OMC (KREPS, 1990; ROSENDORFF, 2005). Esses custos assumem três formas distintas: (i) custos de retaliação, quando o proponente opta por implementar uma decisão final contra a outra parte e suspende concessões comerciais, ou impõe sanções econômicas; ${ }^{6}$ (ii) custos de reputação, quando a parte culpada se recusa a cumprir uma decisão adversa; e (iii) benefícios comerciais bilaterais que deixam de ser realizados enquanto a barreira comercial permanecer em vigor. ${ }^{7}$

De acordo com a teoria dos jogos tradicional, os dois jogadores escolheriam suas estratégias dominantes, que implicam não-cooperação, e terminariam o jogo em um equilíbrio subparetiano. ${ }^{8}$ Fica claro que o dilema do prisioneiro não capta a tradição empírica de solução amigável do sistema GATT/OMC. Com o objetivo de melhor compreender os limites da teoria dos jogos tradicional nesse aspecto, passo em revista alguns dos pressupostos da teoria e confronto expectativas teóricas com os resultados empíricos no que diz respeito à tradição de 
solução amigável e de cooperação no âmbito das disputas comerciais na OMC.

\section{A Teoria dos Jogos Tradicional e suas Limitações}

Nos modelos da teoria dos jogos tradicional, os jogadores escolhem estratégias simultaneamente e não há possibilidade de comunicação entre eles. O resultado do jogo é determinado de forma míope, por meio de cálculos de estratégia dominante e de análises de equilíbrio. Diante das recompensas associadas ao dilema do prisioneiro, somente existe possibilidade de cooperação se o jogo se repetir indefinidamente (KREPS, 1990).

O raciocínio míope implica que os jogadores, ao decidirem suas estratégias, não levam em consideração que o outro jogador pode ter incentivos para postergar um movimento, que levaria a um resultado preferido, em um momento posterior. Entretanto, na vida real, indivíduos freqüentemente antecipam movimentos e contramovimentos com o objetivo de alcançar determinados resultados no longo prazo. Para Brams (1994, p. 80), o Plano Marshall constitui um bom exemplo do raciocínio não-míope. No lugar de guardar todos os espólios da guerra para si e impingir uma punição severa aos países vencidos, como aconteceu ao final da Primeira Guerra Mundial, os arquitetos do plano optaram por reconstruir a Alemanha e promover uma Europa próspera, o que em última instância iria beneficiá-los.

O segundo pressuposto da teoria dos jogos tradicional que merece reconsideração é a ausência de um ponto de partida no jogo, pelo menos na representação estratégica do mesmo (jogo em forma estratégica ou normal). Na maioria das vezes, indivíduos partem de uma situação (ou resolvem permanecer em uma situação) na qual eles recebem uma determinada recompensa. A mobilização dos jogadores para 
Disputas Comerciais e Magnanimidade: Um

Estudo do Mecanismo de Solução...

deixar o status quo é motivada pela insatisfação com a situação presente, ou pela possibilidade de melhorá-la.

No âmbito das disputas comerciais que chegam ao sistema do GATT/OMC, o ponto de partida, via de regra, é uma barreira comercial imposta pela parte demandada. A decisão de formalizar uma disputa comercial por parte do governo prejudicado freqüentemente é o resultado de pressões por parte de grupos de interesse. Nos Estados Unidos da América (EUA), por exemplo, o escritório do United States Trade Representative (USTR) recebe as demandas das partes interessadas e decide se a barreira comercial em questão é compatível com os standards do GATT/OMC. Se a hipótese de incompatibilidade tem mérito, o USTR seguirá adiante com a alternativa adjudicatória, observadas as considerações políticas pertinentes.

Tendo em vista estas limitações da teoria dos jogos tradicional, a seguir discuto a teoria dos movimentos (TOM), demonstrando como a sua estrutura capta processos decisórios do dia-a-dia com mais naturalidade e precisão que a teoria tradicional. Em um momento subseqüente, eu utilizo a TOM para analisar soluções amigáveis de disputas comerciais na OMC.

\section{Teoria dos Movimentos (TOM)}

Um dos elementos centrais na TOM é a noção de equilíbrio não-míope, ou "os resultados estáveis induzidos pela ação dos jogadores, quando estes incorporam o futuro no seu cálculo estratégico" (BRAMS, 1994, p. 1). ${ }^{9}$ Como a TOM permite aos jogadores que estes se movimentem por diferentes estágios do jogo, a teoria garante pelo menos um equilíbrio não-míope em cada jogo. Além desta característica, a TOM às vezes permite que os jogadores deixem equilíbrios de Nash que são Pareto-inferiores na direção de resultados melhores. Da mesma forma, a TOM também pode criar oportunidades 
para que os jogadores deixem equilíbrios de Nash, que, apesar de $\mathrm{Pa}$ reto-superiores, são instáveis.

Com o objetivo de analisar o raciocínio de longo prazo, a TOM incorpora mecanismos dos jogos em forma extensiva no seu próprio cálculo de equilíbrios. Mais especificamente, as regras da TOM permitem que os jogadores se movimentem de uma célula para a outra, no sentido horário ou anti-horário, por meio de indução inversa. Desta maneira, a forma estratégica do jogo proporciona uma representação simples das escolhas disponíveis para os jogadores, e das recompensas associadas a cada escolha, ao mesmo tempo em que exibe a trajetória para um resultado final estável.

$\mathrm{Na}$ TOM, o jogo começa em um estágio inicial. Contrariamente aos pressupostos da teoria dos jogos tradicional, o estágio em que o jogo tem início é importante. Além do mais, os jogadores não se movimentam simultaneamente, mas sim em passos estritamente alternados. A determinação de qual jogador se movimentará primeiro depende de uma análise prévia, por meio da qual a racionalidade das escolhas dos jogadores será interpretada, no status quo. Se for racional para um jogador que ele se movimente, enquanto na ausência de movimento reside a racionalidade do outro jogador, o primeiro jogador terá prioridade (BRAMS, 1994, p. 28).

Brams (1994, p. 1) identifica 78 jogos 2 x 2 ordinais distintos, dos quais 57 são jogos de conflito. Neste artigo, detenho-me sobre um subgrupo destes 57 jogos: os doze jogos em que magnanimidade aparece como uma alternativa racional para um dos dois jogadores. Propõe-se que as disputas comerciais na OMC se circunscrevem aos doze jogos que ilustram o Jogo de Magnanimidade, cuja forma genérica se encontra descrita nos próximos parágrafos. Por meio da TOM, associa-se cada um dos resultados possíveis em um processo adjudicatório no MSC a um subconjunto dos doze jogos compreendidos no Jogo de Magnanimidade. 
O Jogo de Magnanimidade exaure todos os possíveis desdobramentos de disputas na OMC, dado que as combinações de resultados possíveis, assim como a hierarquia de preferências entre essas combinações, compreendem todas as escolhas à disposição das partes em uma disputa comercial. Como mencionado acima, essas escolhas são: escalada da disputa e solução amigável. A escalada resulta quando uma ou ambas as partes escolhem não cooperar. A ausência de cooperação define-se pela decisão de rejeitar acertos com relação à barreira comercial objeto da disputa. A solução amigável ocorre quando ambas as partes optam por aceitar uma acomodação com relação à barreira comercial em questão e, desta forma, chegam a um resultado que é mutuamente aceitável. ${ }^{10}$

Brams (1994) determina seis regras de jogo na TOM, para jogos em que há dois jogadores e cada jogador tem duas estratégias:

1. 'O jogo começa em um resultado, chamado de 'estado inicial', que se encontra na interseção entre uma linha e uma coluna, em uma matriz 2 x 2" (BRAMS, 1994, p. 24).

2. "Cada jogador pode trocar de estratégia unilateralmente e desta forma mudar do estado inicial para um novo estado, na mesma linha ou coluna que o estado inicial. O jogador que mudar de estratégia é chamado de jogador 1" (BRAMS, 1994, p. 24).

3. "O jogador 2 pode responder por meio de uma mudança unilateral de estratégia, desta forma alcançando um novo estado" (BRAMS, 1994, p. 24).

4. "As respostas alternadas continuam até que o jogador (1 ou 2) que tem a prerrogativa de se movimentar decide não mudar de estratégia. Quando isto acontece, o jogo termina em um 'estado final', que constitui o 'resultado' do jogo” (BRAMS, 1994, p. 24).

5. "Um jogador não deixará o estado inicial se este movimento: (i) leva a um estado final menos desejável que o estado inicial (ou resul- 
tado); ou (ii) retorna o jogo para o estado inicial (fazendo do estado inicial o resultado)" (BRAMS, 1994, p. 25).

6. "Dado que os jogadores têm informação completa sobre as preferências mútuas e agem de acordo com as regras da TOM, cada jogador leva em consideração as conseqüências das escolhas racionais do outro jogador, assim como as suas próprias escolhas, quando decide se vai mudar do estado inicial ou não, com base em indução inversa. Se for racional para um jogador deixar o estado inicial, enquanto para o outro jogador a racionalidade implica em permanecer no estado inicial, o jogador que se movimenta terá 'precedência': seu movimento prevalece sobre a ação do jogador que permaneceu. Desta forma, o resultado será induzido pelo jogador que se movimenta" (BRAMS, 1994, p. 28).

Utilizando-se destas regras de jogo, Brams (1994) propõe um jogo de magnanimidade genérico, em que as recompensas são dispostas de forma incompleta. Eu utilizo o Jogo de Magnanimidade para analisar disputas comerciais na OMC, em que os jogadores são a parte que inicia a disputa (iniciante) e a parte demandada. Nesta aplicação do Jogo de Magnanimidade, o iniciante tem duas estratégias: continuar com o processo adjudicatório ou propor uma solução amigável. A parte demandada também tem duas estratégias: cooperar ou não. $\mathrm{O}$ significado da cooperação pela parte demandada será especificado abaixo, uma vez que ele está relacionado à estratégia adotada pelo iniciante.

\section{Jogo de Magnanimidade Genérico Aplícado a uma Disputa Comercial na OMC}

A parte que submete a disputa comercial, chamada aqui de iniciante, sempre começa o jogo por meio de um requerimento para que um painel seja formado, depois que as negociações iniciais não lograram 


\section{Disputas Comerciais e Magnanimidade: Um Estudo do Mecanismo de Solução...}

alcançar uma solução amigável. A partir do momento em que o painel for formado, o iniciante pode aceitar uma nova proposta de solução amigável ou deixar que a disputa siga o procedimento adjudicatório, que, ao final, levará a uma decisão jurídica vinculante de primeira instância. Quando o iniciante opta por seguir o procedimento adjudicatório, a parte demandada pode cooperar ou não.

Cooperação pela parte demandada equivale ao cumprimento do conteúdo da decisão de primeira instância, promulgada pelo painel de peritos. A parte demandada pode também escolher não cooperar, e em seguida enviar a disputa comercial para uma segunda instância do procedimento adjudicatório: o processo perante o órgão de apelação. Eu parto do pressuposto de que uma solução amigável ocorre quando ambas as partes optam por cooperar (célula II). A Tabela 2 ilustra os três resultados possíveis para os jogadores. ${ }^{11}$

\section{Tabela 2}

Jogo de Magnanimidade Genérico

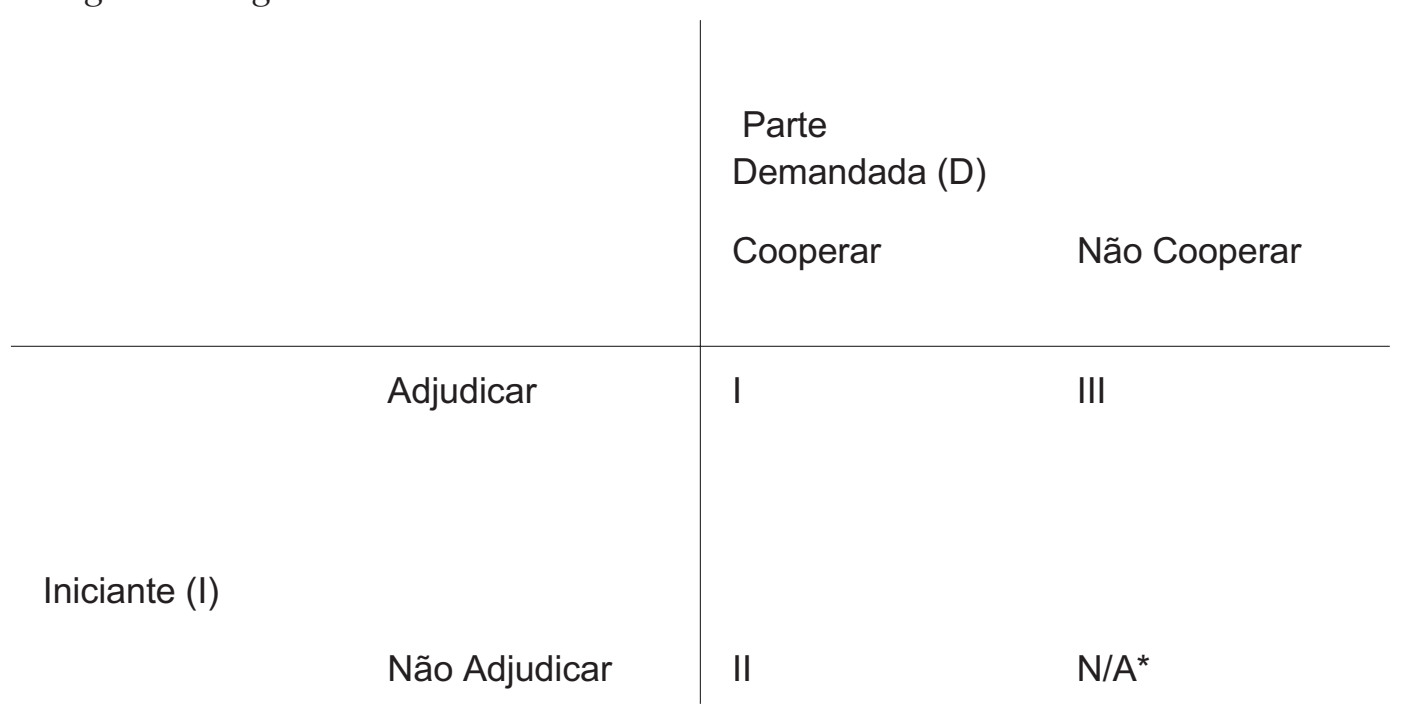

Fonte: Brams (1994, p. 76).

Chave: $(\mathrm{x}, \mathrm{y})=($ recompensa para I, recompensa para $\mathrm{D})$.

$O$ jogo começa na célula I, o estado inicial.

${ }^{*} \mathrm{~N} / \mathrm{A}$ = não se aplica.

I = Adjudicação.

II = Solução amigável.

III = Ausência de solução amigável. 
Brams (1994, p. 77) faz o seguinte comentário sobre a análise de equilíbrio no jogo de magnanimidade genérico: "Este ordenamento parcial dos jogadores no Jogo de Magnanimidade não transforma nenhum estado em um equilíbrio de Nash, tampouco atribui uma estratégia dominante a qualquer dos jogadores, na teoria dos jogos tradicional. Da mesma forma, de acordo com a TOM, nenhum dos estados do Jogo de Magnanimidade constitui um equilibrio nao-míope"

Na célula I, após o requerimento do iniciante para que um painel seja formado, este painel promulga uma decisão em primeira instância, e as partes (tanto a parte iniciante quanto a parte demandada) aceitam a decisão e cumprem com as suas recomendações. O cumprimento dos termos da decisão pela parte demandada, pelo iniciante ou por ambas as partes, na hipótese de uma decisão mista, põe fim à disputa comercial e conclui o procedimento adjudicatório. De aqui em diante, a célula I é também chamada de "adjudicação".

Na célula II, o iniciante e a parte demandada chegam a uma solução amigável antes da decisão do painel, em primeira instância. Nesta análise, é irrelevante se o painel chegou a ser formado ou não. O resultado de solução amigável interrompe o procedimento adjudicatório e impede que uma eventual decisão do painel seja levada a cabo. A célula II é também chamada de "solução amigável".

Na célula III, a disputa comercial terá alcançado a segunda instância de jurisdição, em que o órgão de apelação está encarregado de proferir uma decisão final. Esta decisão final põe termo ao procedimento adjudicatório dentro da OMC e, com exceção dos procedimentos relativos ao cumprimento das obrigações jurídicas criadas, a decisão final conclui o papel da OMC na disputa. Se o cumprimento voluntário das obrigações jurídicas criadas ocorre ou não, ultrapassa o âmbito de análise deste artigo. A célula III é também chamada de "ausência de solução amigável”. A esta aplicação do Jogo de Magnanimidade a disputas comerciais, correspondem as seguintes preferências. 
A célula I é o melhor resultado para o iniciante. Na célula I, o iniciante utiliza o sistema para alcançar uma decisão favorável e a parte demandada concorda com os termos da decisão. Desta forma, os benefícios do comércio bilateral são restaurados e custos de retaliação são poupados. A decisão do painel tornará os termos da disputa comercial mais claros, reduzindo o poder de barganha da parte demandada, na hipótese de uma eventual negociação amigável.

Em seguida, o iniciante prefere a célula II à célula III, por conta das perdas associadas ao comércio bilateral, e da possibilidade de custos de retaliação. Na célula II, as partes chegam a uma solução amigável antes da decisão do painel porque o iniciante age de forma magnânima, com vistas a evitar o pior resultado, representado pela célula III. Ao escolher "não adjudicar", o iniciante induz o resultado que minimiza as perdas relacionadas ao comércio bilateral, evita os custos de retaliação (a cargo do iniciante) e os custos de reputação (que incorrem sobre a parte demandada).

Finalmente, o resultado representado na célula III é o pior para o iniciante, dadas as perdas de comércio e os custos de retaliação. Quanto mais tempo durar a disputa comercial, maiores as perdas comerciais para as partes. Em termos de custos de retaliação, em última instâcia, o iniciante é responsável pela arquitetura de um mecanismo de punição, após a decisão contrária à parte demandada. Essa punição envolve custos e não há qualquer garantia de que a barreira comercial ilegal seja removida, caso a parte demandada resolva descumprir com a decisão.

Em resumo, a hierarquia de preferências para o iniciante é a seguinte:

(I) Adjudicação > (II) solução amigável > (III) ausência de solução amigável.

A parte demandada prefere a célula II a todos os outros resultados. Neste caso, o iniciante e a parte demandada chegam a uma solução 
amigável antes que o painel decida a disputa. Como conseqüência desta solução amigável, a parte demandada põe fim à barreira comercial objeto da disputa sem que incidam custos de reputação. Os benefícios do comércio bilateral também são restaurados.

No que se refere às células I e III, as preferências da parte demandada dependerão das circunstâncias da disputa em questão. Se as chances de uma decisão favorável na segunda instância são altas, a célula III será o segundo melhor resultado para a parte demandada. Em contrapartida, se as chances de uma decisão favorável em última instância são baixas, a parte demandada prefere a célula I à célula III.

A despeito do que foi colocado acima, existe uma circunstância em que a parte demandada prefere a célula III à célula II (ausência de uma solução amigável > solução amigável). Esta hierarquia de preferências ocorre quando a parte demandada busca uma posição jurisprudencial, ou precedente. Nestes casos, faz-se necessário que a disputa siga a trajetória do procedimento adjudicatório até a última instância: a recomendação por parte do órgão de apelação. Esses casos impõem um custo extra aos termos da solução amigável. Se os termos da proposta de solução amigável não forem suficientemente atrativos, a parte demandada seguirá adiante com a disputa até que uma decisão final seja proferida, levando à seguinte hierarquia de preferências: ausência de solução amigável > solução amigável > adjudicação.

Por fim, a célula II pode ser o segundo melhor resultado para a parte demandada quando a "ausência de uma solução amigável" for a sua primeira escolha. Hierarquia de preferências para a parte demandada:

- primeira preferência: às vezes solução amigável, às vezes ausência de solução amigável;

- segunda preferência: às vezes adjudicação, às vezes ausência de solução amigável, às vezes solução amigável; 
- última preferência: às vezes adjudicação, às vezes ausência de solução amigável.

\section{Análise de Equilíbrio no Jogo de Magnanimidade Genérico}

A seguir, detalho os equilíbrios encontrados quando o jogo de magnanimidade genérico é especificado. Para tanto, faz-se necessário organizar os resultados das células I, II e III de forma ordinal.

Os doze jogos que resultam quando especificamos os resultados podem ser agrupados em três classes distintas: (i) quatro jogos têm equilíbrio não-míope na célula II, e ilustram situações quando a ação magnânima é racional para o iniciante, e magnanimidade conduz a uma solução amigável antes da decisão do painel (jogos de classe 1); (ii) quatro jogos têm equilíbrio não-míope na célula I, e ilustram situações em que a disputa termina após a decisão do painel (jogos de classe 2); (iii) um jogo tem equilíbrio não-míope na célula III, e ilustra disputas que são decididas em grau de recurso (jogo de classe 3). Outros três jogos não têm equivalentes em disputas comerciais e não serão discutidos neste artigo. Os doze jogos encontram-se representados na Figura 1.

\section{Figura 1}

Jogo de Magnanimidade Genérico

Jogos de classe 1: magnanimidade leva ao equilíbrio não-míope (não adjudicar, cooperar).

\begin{tabular}{llllllll}
$\mathbf{2 8}$ & & $\mathbf{2 9}$ & & $\mathbf{3 2}$ & \multicolumn{5}{c}{$\mathbf{5 0}$} \\
4,1 & 2,2 & 4,1 & 1,2 & 4,1 & 2,2 & 4,2 & 1,1 \\
3,4 & 1,3 & $\underline{3,4}$ & 2,3 & $\underline{3,3}$ & 1,4 & $\underline{3,4}$ & 2,3 \\
\hline
\end{tabular}


Jogos de classe 2: solução amigável qualificada leva ao equilíbrio não-míope (adjudicar, cooperar).

\begin{tabular}{|llllllll|}
\hline $\mathbf{2 2 a}$ & & $\mathbf{3 3}$ & & $\mathbf{3 4}$ & & $\mathbf{3 5}$ & \\
$\underline{4,2}$ & 2,1 & $\underline{4,3}$ & 2,1 & $\underline{4,3}$ & 1,1 & $\underline{4,2}$ & 2,1 \\
3,3 & 1,4 & 3,4 & 1,2 & 3,4 & 2,2 & 3,4 & 1,3
\end{tabular}

Jogos de classe 3: escalar a disputa leva ao equilíbrio não-míope (adjudicar, não cooperar).

\section{1 \\ $4,1 \quad \underline{2,3}$ \\ $3,2 \quad 1,4$}

Os três jogos abaixo também estão compreendidos no Jogo de Magnanimidade, mas não se aplicam a disputas comerciais na OMC.

\begin{tabular}{|c|c|c|c|c|c|}
\hline & 18 & $22 \mathrm{l}$ & & 57 & \\
\hline 4,1 & 1,3 & 4,1 & 1,2 & 4,2 & 1,1 \\
\hline 3,2 & $\underline{2,4}$ & 3,3 & $\underline{2,4}$ & $\underline{3,3}$ & $\underline{2,4}$ \\
\hline
\end{tabular}

Ao todo, são doze jogos ordinais específicos compreendidos no Jogo de Magnanimidade (BRAMS, 1994, p. 77).

Uma vez especificadas as recompensas associadas aos nove jogos que são relevantes para a aplicação do Jogo de Magnanimidade a disputas comerciais na OMC, serão analisadas em seguida a hierarquia de preferências da parte demandada e a repercussão que esta hierarquia exerce sobre a ação magnânima por parte do iniciante. Todas as classes de jogos são expostas, com vistas a propor uma hierarquia de preferências condicional para a parte demandada. 
Disputas Comerciais e Magnanimidade: Um

Estudo do Mecanismo de Solução...

\section{Figura 2}

Jogos de classe 1: solução amigável constitui o equilíbrio não-míope (não adjudicar, cooperar).

\begin{tabular}{|c|c|c|c|c|c|c|c|}
\hline 28 & & 29 & & 32 & & 50 & \\
\hline 4,1 & 2,2 & 4,1 & 1,2 & 4,1 & 2,2 & 4,2 & 1,1 \\
\hline 3,4 & 1,3 & $\underline{3,4}$ & 2,3 & $\underline{3,3}$ & 1,4 & $\underline{3,4}$ & 2,3 \\
\hline
\end{tabular}

Fonte: Brams (1994, p. 77).

Nos jogos de classe 1, a célula II é o melhor resultado para a parte demandada. O segundo melhor resultado é a célula III, nos jogos 28, 29 e 32. No jogo 50, a segunda melhor opção para a parte demandada é a célula I. Como a célula IV (segunda linha da direita) não tem equivalente na análise de disputas comerciais na OMC, as recompensas associadas a esta célula são ignoradas.

Para identificar a hierarquia de preferências real da parte demandada, faz-se necessário especificar o jogo que está sendo jogado, entre os quatro jogos de classe 1. Essa especificação requer mais informações sobre a disputa. Sempre que o nível de incerteza com relação ao resultado do procedimento adjudicatório em nível de recurso for alto, a parte demandada vai preferir uma solução amigável após a decisão do painel à continuação do procedimento adjudicatório (célula I > célula III). Em contrapartida, quando a parte demandada acreditar que a decisão em grau de recurso trará benefícios, ela vai preferir a célula III à célula I. Vale salientar que, independentemente de qual seja a segunda e a terceira melhor opção para a parte demandada, a sua primeira escolha sempre será a célula II, nos jogos de classe 1. Essa é uma condição suficiente para que o iniciante aja de forma magnânima.

Assim, temos:

Em se tratando dos jogos 28, 29 ou 32, a hierarquia de preferências da parte demandada será:

Solução amigável > ausência de solução amigável > adjudicação. 
Em se tratando do jogo 50, a hierarquia de preferências da parte demandada será:

Solução amigável > adjudicação > ausência de solução amigável.

Para os jogos de classe 2, a real hierarquia de preferências da parte demandada depende da seguinte análise.

\section{Figura 3}

Jogos de classe 2: adjudicação constitui o equilíbrio não-míope (adjudicação, cooperação).

\begin{tabular}{|llllllll|}
\hline $\mathbf{2 2 a}$ & & $\mathbf{3 3}$ & & $\mathbf{3 4}$ & & $\mathbf{3 5}$ & \\
$\frac{4,2}{3,3}$ & 2,1 & $\underline{4,3}$ & 2,1 & $\underline{4,3}$ & 1,1 & $\underline{4,2}$ & 2,1 \\
3,4 & 3,4 & 1,2 & 3,4 & 2,2 & 3,4 & 1,3 \\
Fonte: Brams (1994, p. 77$).$ & & & & &
\end{tabular}

Nos jogos de classe 2, a hierarquia de preferências da parte demandada é consistente e incondicional. A parte demandada sempre vai optar pela célula II, em seguida pela célula I e, por último, pela célula III. Com base no conhecimento prévio desta hierarquia incondicional, o iniciante escolhe o seu melhor resultado (célula I) e persiste nesta escolha. Desta forma, temos:

Em se tratando dos jogos 22a, 33, 34 ou 35, a ordem de preferências da parte demandada será:

Solução amigável > adjudicação > ausência de solução amigável.

Por fim, para os jogos de classe 3, fazemos a seguinte análise.

\section{Figura 4}

Jogos de classe 3: ausência de solução amigável constitui o equilíbrio não-míope (adjudicar, não cooperar).

$\begin{array}{ll}\mathbf{1 1} & \\ 4,1 & \underline{2,3} \\ 3,2 & 1,4 \\ \text { Fonte: Brams (1994, p. 77). }\end{array}$


Nos jogos de classe 3, a hierarquia de preferências da parte demandada é precisamente o inverso daquela para os jogos de classe 2. Essa hierarquia configura um jogo de puro conflito, em que o melhor resultado para a parte demandada corresponde à ausência de solução amigável. Isto acontece porque, em algumas disputas comerciais perante a OMC, a parte demandada tem um interesse preponderante em influenciar a jurisprudência e, para este fim, faz-se necessário seguir adiante com a disputa a fim de que o órgão de apelação pronuncie uma decisão em última instância.

Argumentamos que o jogo de magnanimidade genérico capta a realidade empírica das disputas comerciais na OMC de maneira abrangente e exaustiva. A recorrência de soluções amigáveis somente pode ser explicada se recorrermos aos quatro jogos de classe 1 acima referidos - aqueles em que a ação magnânima é racional. Neste grupo de jogos, utilizando indução inversa, os jogadores chegam à conclusão de que, partindo de um estado inicial específico (célula I), magnanimidade constitui uma ação racional para o iniciante.

\section{Dados Empíricos das Disputas Comerciais na OMC}

Com base no resultado das 336 disputas que constituem o objeto da análise empírica neste artigo, a seguir eu discuto a abrangência do modelo com relação ao resultado dessas disputas. Ha três categorias de resultados possíveis, no âmbito da OMC:

1) solução amigável, quando as partes chegam a um entendimento antes da decisão vinculante por parte do painel;

2) adjudicação, quando as partes chegam a um entendimento após a promulgação de uma decisão final por parte do painel (esta decisão precisa ser confirmada pelo órgão de solução de controvérsias); e 
3) ausência de solução amigável, quando existe uma decisão do órgão de apelação e esta é adotada pelo órgão de solução de controvérsias. $^{12}$

Estas categorias de disputas se encontram contempladas nos três resultados do Jogo de Magnanimidade, na forma como o aplicamos a disputas comerciais na OMC. A grande maioria dos casos corresponde à célula II, ou o resultado que decorre da ação magnânima por parte do iniciante. A segunda maior categoria corresponde à célula I, enquanto a categoria "ausência de solução amigável" aparece em terceiro lugar.

A Tabela 3, a seguir, ilustra esses três resultados e as células correspondentes, no jogo de magnanimidade genérico.

Na próxima seção, três disputas comerciais que foram levadas à OMC são discutidas, com o objetivo de ilustrar os resultados nas células I, II e III: o caso do peixe-espada (jogo de classe 1), o caso da Seção 301 (jogo de classe 2) e o caso camarão-tartaruga (jogo de classe 3). ${ }^{13}$

\section{- Caso do Peixe-espada (Comunidade Européia versus Chile, Ds 193)}

O caso do peixe-espada teve início quando a União Européia (UE) protestou contra uma regulamentação chilena que fechava os portos em todo o país para barcos de pesca europeus transportando peixe-espada. A medida buscava proteger o peixe-espada - uma espécie ameaçada de extinção. A despeito dos objetivos de proteção ambiental, a medida comprometia a capacidade de exportação da frota européia (sobretudo a espanhola), ao limitar as operações de pesca de peixe-espada em águas internacionais, inclusive águas vizinhas ao limite da zona de exploração econômica exclusiva chilena. Os dispositi- 


\section{Tabela 3}

Resultados de Disputas Comerciais na OMC e o Jogo de Magnanimidade Genérico

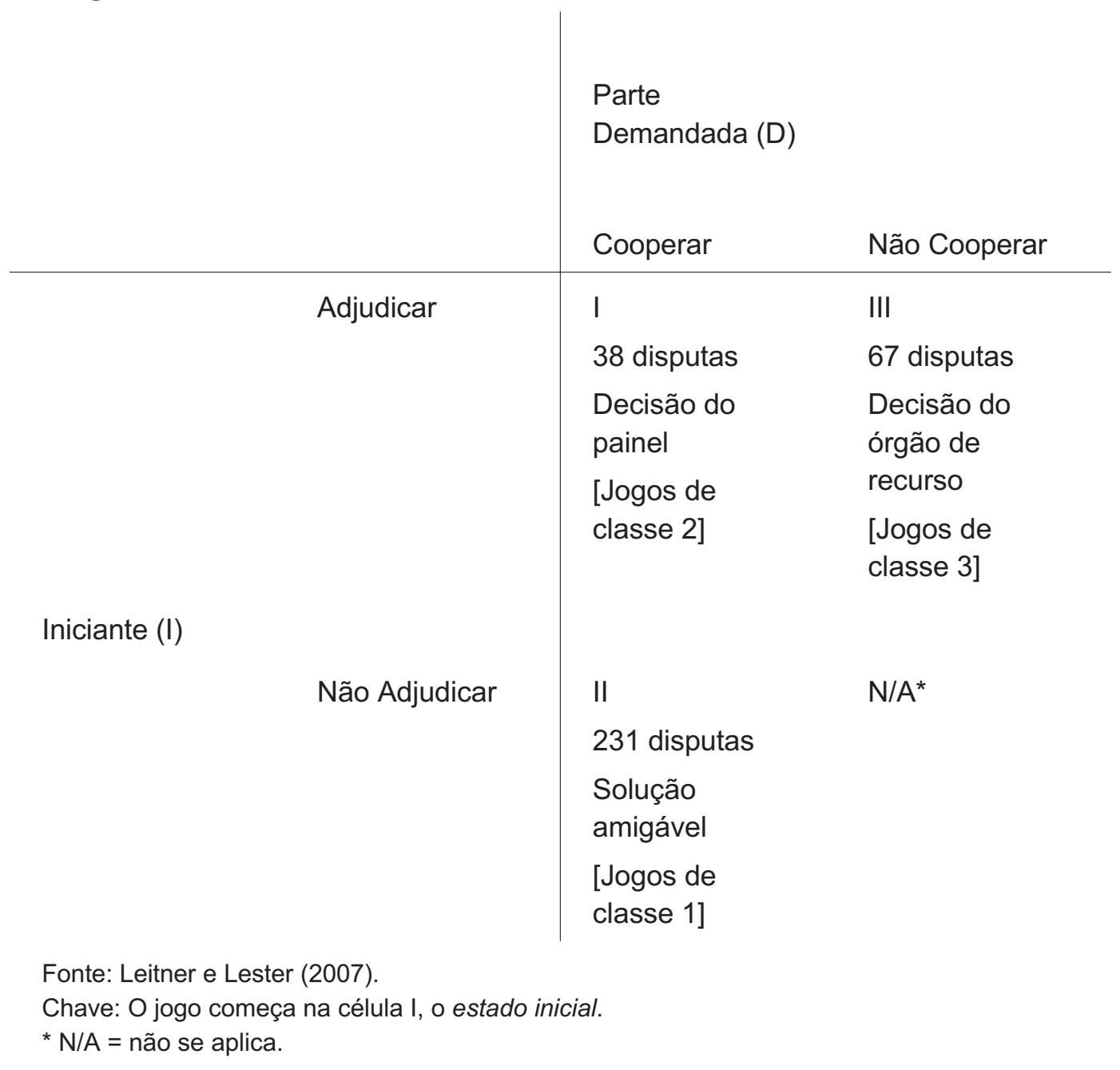

vos do GATT/OMC aplicáveis, assim como os artigos relevantes da Convenção de Direito Marítimo (UNITED NATIONS, 1982), oferecem duas perspectivas jurídicas contrastantes:

Artigo V, Parágrafo segundo do GATT:

Deve haver liberdade de trânsito através do território de cada parte contratante, por meio das rotas mais convenientes para o transporte inter- 
nacional, para o tráfego em trânsito para, ou partindo do território de, outras partes contratantes. Nenhuma distinção deve ser feita com base na bandeira das embarcações, seu local de origem, de partida, entrada, saída ou destino, ou quaisquer outras circunstâncias relativas a propriedade de cargas, embarcações ou outros meios de transporte (WTO, 1947).

A UE argumentou que a regulamentação chilena violava o art. V (2) do GATT, e que o painel deveria declarar que a medida não era consistente com as obrigações do Chile perante os acordos do GATT/OMC. O Chile respondeu que a medida tinha respaldo nas exceções previstas no art. XX do GATT, o qual isenta Estados-membros das obrigações de tratamento semelhante e cláusula da nação mais favorecida, em determinadas circunstâncias:

Artigo XX, Parágrafos (b) e (g) do GATT:

Observada a obrigação de que tais medidas não sejam aplicadas de uma maneira que constituam um mecanismo de discriminação arbitrária ou injustificável entre países onde as mesmas condições prevalecem, ou uma barreira comercial disfarçada, nenhum dispositivo deste Acordo deve ser interpretado de forma a impedir a adoção ou o cumprimento pelas partes contratantes de medidas: (b) necessárias para a proteção da vida ou da saúde humana, animal ou vegetal; $[\ldots]$ (g) relativas à conservação de recursos naturais exauríveis, se estas medidas forem efetivadas conjuntamente a restrições na produção e consumo domésticos (WTO, 1947).

O Tribunal Internacional de Direito Marítimo havia julgado um caso semelhante, em que a pesca comercial de uma espécie de atum, também ameaçada de extinção, foi declarada contrária às obrigações dos 


\section{Disputas Comerciais e Magnanimidade: Um Estudo do Mecanismo de Solução...}

países-membros da Convenção. Nessa decisão, o Tribunal reafirmou o compromisso dos países-membros no sentido de: (i) tomar as medidas necessárias para a conservação das espécies ameaçadas de extinção; e (ii) coordenar os respectivos esforços nessa tarefa. No caso do atum, o julgamento foi baseado em alguns dos mesmos dispositivos da Convenção que o Chile levantou no caso do peixe-espada, em particular os artigos 117 e 118 :

"Artigo 117: Todos os Estados têm o dever de tomar, ou de cooperar com outros Estados na tomada de, medidas necessárias para os seus respectivos nacionais, relativas à conservação dos recursos naturais dos oceanos" (UNITED NATIONS, 1982).

Artigo 118: Os Estados devem cooperar entre si na conservação e administração dos recursos dos oceanos. Os Estados cujos nacionais exploram recursos naturais idênticos, ou recursos distintos na mesma área, devem se engajar em uma negociação com o objetivo de tomar as medidas necessárias à conservação dos recursos naturais afetados. Os Estados devem, quando apropriado, cooperar no sentido de estabelecer organizações de pesca regionais ou subregionais para esse fim (UNITED NATIONS, 1982).

Os dispositivos transcritos acima ilustram distinções fundamentais entre o regime de direito comercial internacional e o regime de direito marítimo internacional. ${ }^{14}$ A tensão entre os objetivos dos dois regimes é perceptível a olhos vistos; essa tensão funcionou como pano de fundo para o caso do peixe-espada, fornecendo incentivos que motivaram as partes a buscarem uma solução amigável.

Na percepção do Chile, a OMC provavelmente decidiria a favor da UE. Essa expectativa tinha respaldo na tradição de julgamentos favoráveis à parte iniciante (BUSCH; REINHARDT, 2003, p. 724), assim como na jurisprudência pertinente a casos que envolviam barreiras comerciais e proteção ambiental, como o caso camarão-tartaruga 
e os dois casos dos golfinhos. ${ }^{15}$ As chances de uma decisão pró-Chile na OMC eram bastante remotas. Na qualidade de parte demandada, o Chile iria provavelmente se deparar com decisões adversas na primeira e segunda instância.

Para além de uma decisão adversa, que teria um impacto devastador sobre as políticas chilenas para a conservação do peixe-espada, o Chile teria custos de reputação associados com a decisão negativa. Tendo em vista essas consequiências, o Chile estava predisposto a buscar uma solução amigável; além disso, quanto antes o acordo chegasse, menores os danos para a reputação do Chile no âmbito do regime internacional de liberalização comercial. ${ }^{16}$ Para o Chile, uma solução amigável antes da decisão do painel seria o melhor resultado possível. O Chile entrou com o caso no Tribunal Internacional de Direito Marítimo com o objetivo de incrementar o seu poder de barganha durante a negociação com a UE, como sugere Shamsey (2002, p. 517):

Independentemente de ter sido uma feliz coincidência ou uma ação calculada, a decisão do Chile de entrar com o caso no Tribunal Marítimo, apenas algumas semanas depois que a OMC aceitou a mesma disputa, teria um papel muito importante no sentido de neutralizar a força de uma eventual decisão do órgão de apelação da OMC.

Portanto, a hierarquia de preferências do Chile é a seguinte:

Solução amigável > adjudicação > ausência de solução amigável.

Na percepção da UE, a OMC provavelmente iria decidir a seu favor, mas existia um risco real e iminente de uma decisão adversa no Tribunal Marítimo, tendo em vista o precedente dos casos do atum. A posição européia também foi influenciada pela possibilidade de custos de retaliação e maiores perdas no comércio bilateral. O melhor resultado para a UE seria uma decisão a favor da parte iniciante em pri- 


\section{Disputas Comerciais e Magnanimidade: Um \\ Estudo do Mecanismo de Solução...}

meira instância, seguida do cumprimento imediato por parte do Chile. Nessas circunstâncias, as perdas no comércio bilateral seriam minimizadas, e os custos de retaliação poupados.

Se o Chile não houvesse submetido a disputa ao Tribunal Marítimo, a UE provavelmente teria buscado o seu melhor resultado. Mas diante da ameaça de uma decisão adversa por parte daquele tribunal, a distância entre o melhor resultado para a UE (adjudicação) e o segundo melhor resultado (solução amigável) foi reduzida. Ainda que o resultado preferido para a UE fosse o cumprimento por parte do Chile de uma decisão do painel, a aproximação do primeiro e segundo resultados tornou a opção por magnanimidade mais atrativa. Desta forma, a UE resolveu abandonar a briga pelo seu resultado preferido e passou a buscar o segundo melhor resultado, que correspondia a um equilíbrio não-míope, tendo em vista que o Chile não tinha qualquer incentivo para deixar esse equilíbrio.

Recapturando a hierarquia de preferências da UE:

Adjudicação > solução amigável > ausência de solução amigável.

Este caso ilustra as circunstâncias que levaram a UE a agir de forma magnânima, eventualmente chegando a uma solução amigável antes da decisão do painel. Muito embora seja impossível antecipar os desdobramentos dos dois casos, é razoável argumentar que a disputa no Tribunal Marítimo facilitou uma solução amigável na OMC. Para os propósitos deste artigo, a possibilidade de uma decisão adversa no Tribunal Marítimo fez com que a possibilidade de uma ação magnânima fosse mais atrativa para a UE, criando incentivos para que os europeus deixassem a célula I (estado inicial) na direção da célula II (solução amigável). Os incentivos que o Chile tinha para buscar uma solução amigável eram fortes desde o início, mas o movimento da UE na direção da magnanimidade certamente incrementou os termos da solução amigável em benefício dos chilenos. 


\section{Caso da Seção 301 (União Européia versus Estados Unidos - WT/DS152/R, 22 de Dezembro de 1999)}

Neste caso, a UE fez objeção a um conjunto de dispositivos do Estatuto de Comércio norte-americano de 1974, mais especificamente as Seções 301-310 deste documento (comumente referidas somente por Seção 301), que autoriza o USTR a valer-se de medidas unilaterais contra parceiros comerciais cujas ações nulificam ou comprometem os interesses comerciais dos Estados Unidos. A Seção 301 havia sido utilizada no passado para forçar a remoção de políticas comerciais restritivas na esfera da propriedade intelectual, por exemplo. A partir de uma investigação com base na Seção 301, o USTR pode autorizar a suspensão de concessões ou até mesmo impor sanções comerciais sobre setores específicos da indústria estrangeira, como medida retaliatória contra a nulificação ou o comprometimento dos interesses comerciais norte-americanos potencialmente lesados. ${ }^{17}$ A UE alegou que as Seções 301-310 do Estatuto de Comércio de 1974 violavam os artigos 3, 21, 22 e 23 do Mecanismo de Solução de Controvérsias e o artigo XVI:4 do Acordo da OMC. Mais especificamente, a UE argumentou que os prazos bastante estritos utilizados pelo USTR para iniciar e prosseguir com uma investigação no âmbito da Seção 301 poderiam levar a uma conclusão, e subseqüentemente a medidas retaliatórias, antes da adoção de uma decisão final no âmbito da OMC. ${ }^{18}$

Após a submissão da disputa pela UE, dezessete países reservaram o seu direito de participar dos procedimentos junto ao painel da OMC, na qualidade de terceiros interessados (WTO, 1999, p. 3). O número de países interessados em acompanhar os desdobramentos do caso mais de perto confirma que a questão era de fato bastante sensível, e ultrapassava os limites do relacionamento bilateral entre os Estados Unidos e a União Européia. Depois de examinar cada uma das seções 


\section{Disputas Comerciais e Magnanimidade: Um}

Estudo do Mecanismo de Solução...

do Estatuto de 1974 objeto da disputa, o painel julgou a legislação norte-americana contrária ao artigo 23 do Mecanismo de Solução de Controvérsias (MSC). O painel afirmou ainda que a regulamentação poderia ter consequiências intimidatórias no mercado, indo de encontro, portanto, aos princípios fundadores dos acordos do GATT/OMC.

Entretanto, após dissecar as Seções 301-310 do Estatuto de 1974, em particular a Seção 304, o painel conclui que "a violação prima facie foi de fato legalmente removida neste caso, e não mais existe" (WTO, 1999). A conclusão do painel pode ser resumida nos seguintes pontos: (i) as Seções 301-310 da referida legislação norte-americana podem potencialmente constituir uma violação dos artigos 21, 22 e 23 do MSC e do artigo XVI:4 do GATT; (ii) como os EUA vinham tomando providências para garantir que tais violações não se concretizassem com relação a membros da OMC, e tendo em vista que essas providências foram institucionalizadas (por meio de um Statement of Administrative Action), as Seções 301-310 estavam, naquele momento, sendo implementadas de maneira consistente com as obrigações dos EUA perante os acordos da OMC.

No caso da Seção 301, chegou-se a um acordo por meio do qual, se os EUA continuassem a implementar o dispositivo questionado com cautela e respeitando os prazos do MSC, não haveria um julgamento de inconsistência. Mas, caso a implementação da Seção 301 assumisse outros padrões e, em particular, se o USTR autorizasse a suspensão de concessões ou medidas retaliatórias antes da adoção de uma decisão final por parte da OMC em uma disputa semelhante, a questão poderia ser trazida novamente à $\mathrm{OMC}$, e desta vez o painel provavelmente decidiria de forma diferente.

Na qualidade de parte iniciante, as chances de uma decisão favorável à UE eram altas. Neste caso específico, as perdas relacionadas ao comércio bilateral não eram uma questão predominante porque a Seção 
301 somente em potencial poderia afetar exportadores europeus, o que transformava o litígio em um dilema de provisão de bens públicos. Tendo em vista essa característica, aparentemente a UE buscava satisfazer as demandas de uma coalizão mais ampla, ao contrário de grupos específicos, cujos interesses comerciais teriam eventualmente sido afetados pela barreira comercial em questão. ${ }^{19}$

Em parte por conta da natureza desta disputa (dilema de provisão de bens públicos), a UE precisava de uma decisão jurisprudencial, levando à seguinte hierarquia de preferências:

Adjudicação > ausência de solução amigável > solução amigável.

Enquanto parte demandada, os EUA tinham as chances de uma decisão adversa contra si. Por outro lado, dadas as preferências da UE, a possibilidade de uma solução amigável era muito remota, a despeito de ser esse o melhor resultado para os norte-americanos. Um resultado intermediário, como o de adjudicação (célula I), parecia atrativo nestas circunstâncias. A preocupação norte-americana foi agravada quando os dezessete países se vincularam à disputa, na qualidade de partes interessadas. A despeito do conteúdo do acordo final, os EUA tinham certeza de que países representando cinqüenta por cento da riqueza mundial estavam observando atentamente. ${ }^{20}$

A hierarquia de preferências dos EUA é a seguinte:

Solução amigável > adjudicação > ausência de solução amigável.

Esta disputa comercial ilustra circunstâncias que levaram a uma solução amigável depois que o painel proferiu a sua decisão. Este resultado é chamado de "solução amigável qualificada", neste artigo, dado que a UE abriu mão da oportunidade de recorrer da decisão na primeira instância, aceitando desta forma o acordo representado pela política de interpretação e de aplicação da Seção 301 que prevalecia na época. 
Disputas Comerciais e Magnanimidade: Um

Estudo do Mecanismo de Solução...

A decisão do painel atende, simultaneamente, às demandas mais importantes do iniciante e da parte demandada. Ao final, o equilíbrio não-míope da célula I foi alcançado graças ao mérito da decisão em primeira instância. Em contrapartida, o painel decide a favor do iniciante quando afirma que a Seção 301 viola o artigo XVI:4 dos acordos da OMC e o artigo 23 do MSC; por outro lado, o painel decide a favor da parte demandada quando conclui que a Seção 301, da forma como estava sendo aplicada pelos EUA, não era incompatível com os acordos da OMC. Do ponto de vista estritamente jurídico, a decisão em primeira instância favorece a parte demandada, o que ocorre em aproximadamente um terço dos casos (BUSCH; REINHARDT, 2003, p. 724).

No âmbito do caso em análise, o resultado "adjudicação" representa um acordo de cavalheiros entre a UE e os EUA, viabilizado pela decisão do painel. Como ambas as partes decidiram não recorrer da decisão, trata-se de uma solução amigável qualificada.

\section{Caso Camarão-Tartaruga (Índia, Malásia, Paquistão e Tailândia versus EUA - WT/DS58/AB/R, 12 de Outubro de 1998)}

O caso do camarão-tartaruga foi submetido à OMC pela Índia, Malásia, Paquistão e Tailândia, após os EUA proibirem a entrada de camarões e produtos derivados no mercado norte-americano cuja pesca acarretava a morte acidental de tartarugas marinhas. As tartarugas marinhas são uma espécie protegida pela Convenção sobre o Comércio Internacional de Espécies da Fauna e Flora Ameaçadas de Extinção. Com o objetivo de proteger as tartarugas marinhas, os EUA haviam aprovado a Seção 609 da Lei 101-162 (Seção 609), que exigia a utilização de dispositivos para excluir tartarugas capturadas acidentalmente em todos os barcos envolvidos na pesca de camarão, inclu- 
sive barcos que pescavam além da zona de exploração econômica exclusiva norte-americana. A implementação da Seção 609 deu-se por meio de um processo de certificação.

Dentre os argumentos que os EUA propuseram em segunda instância, o julgamento do painel no que diz respeito à questão de "discriminação sem justificativa" foi central. Os EUA pediram que o órgão de apelação determinasse: "(b) se o Painel errou ao decidir que a medida em questão constitui discriminação injustificável entre países em que prevalecem as mesmas condições, ficando desta forma fora da abrangência das medidas permitidas pelo Artigo XX do Acordo do GATT de 1994" (WTO, 1998, p. 34).

O painel ficou do lado dos iniciantes nesta questão, aceitando o argumento segundo o qual a barreira comercial norte-americana constituía uma restrição disfarçada ao comércio internacional, dado que a medida não tinha amparo no artigo XX do GATT. Entre outras exceções, o artigo XX autoriza barreiras comerciais que visam proteger recursos naturais ameaçados de extinção. Os iniciantes também argumentaram que as tartarugas marinhas não estavam ameaçadas de extinção. Nesses dois pontos, o órgão de apelação decidiu contrariamente aos argumentos propostos pelos iniciantes. A despeito desta decisão contrária, o órgão de apelação entendeu que a barreira comercial objeto da disputa "foi aplicada pelos Estados Unidos de uma maneira que constitui discriminação arbitrária e injustificável entre Membros da OMC, contrariando os requisitos do chapeau do Artigo XX” (WTO, 1998, parágrafo 186, p. 75). Como conseqüência, a decisão do órgão de apelação recomenda

[...] que o Órgão de Solução de Controvérsias requeira dos Estados Unidos que eles revisem a medida que o Relatório do Painel julgou inconsistente com o Artigo XI do Acordo do GATT de 1994, e não justificável nos termos do Artigo XX do mesmo acordo, de forma a adequá-la 
Disputas Comerciais e Magnanimidade: Um

Estudo do Mecanismo de Solução...

às obrigações dos Estados Unidos no âmbito do Acordo (WTO, 1998, p. 75).

O caso camarão-tartaruga constitui uma típica disputa em que questões de liberalização comercial se encontram emaranhadas com questões de proteção ambiental ou de saúde pública (HOWSE, 2002). Essas disputas são chamadas de "trade and..." pela literatura, que distingue casos em que a barreira comercial é de natureza contínua, por exemplo uma tarifa, de casos em que a barreira é descontínua, por exemplo a proibição norte-americana sob análise. Esses últimos casos oferecem maiores dificuldades quando se trata de chegar a uma solução amigável, porque as partes têm uma margem menor de manobra durante as negociações (GUZMAN; SIMMONS, 2002, p. 2). No caso camarão-tartaruga, os iniciantes pleiteavam a remoção da barreira comercial, ao contrário de uma tarifa menor ou uma política de certificação mais flexível.

O caso camarão-tartaruga ilustra um jogo de classe 3 . Os iniciantes levaram a disputa à $\mathrm{OMC}$ na expectativa de alcançar o melhor resultado: adjudicação para os iniciantes e cooperação por parte dos EUA. Nesta hipótese, a barreira comercial norte-americana seria removida após uma decisão do painel em primeira instância.

Quais as características do caso camarão-tartaruga que o qualificam como um jogo de classe 3? Eu defendo que o caso foi uma das primeiras disputas "trade and..." na OMC; conseqüentemente, o caso gerou incentivos bastante particulares para as partes. ${ }^{21}$ Do ponto de vista dos EUA, uma solução amigável (antes ou depois da decisão do painel) não estabeleceria a jurisprudência pioneira, segundo a qual barreiras comerciais podem ultrapassar a jurisdição territorial dos Estados, quando visam proteger o meio ambiente. Para alcançar esse precedente jurisprudencial de peso, os EUA precisavam seguir adiante com a disputa até o órgão de apelação, desta forma precluindo oportunidades de uma solução amigável. 
A busca de um precedente ambiental influenciou a hierarquia de preferências norte-americana, fazendo com que o resultado da célula IV (adjudicação, não-cooperação) se tornasse mais atrativo. A hierarquia passou a ser:

Ausência de solução amigável > adjudicação > solução amigável.

Tendo em vista os fortes incentivos que os EUA tinham para buscar adjudicação (ou não-cooperação), os iniciantes simplesmente agiram de acordo com as preferências norte-americanas e escolheram a melhor resposta para adjudicação. Ao final, como o melhor resultado para os iniciantes era instável, eles optaram pela célula III. A hierarquia de preferências dos iniciantes ficou assim:

Solução amigável > adjudicação > ausência de solução amigável.

Em termos empíricos, os iniciantes encontravam-se limitados na sua capacidade de trazer os EUA para a mesa de negociação. A resistência norte-americana explica-se, em parte, pela natureza descontínua da questão objeto da disputa (GUZMAN; SIMMONS, 2002, p. 2). Do ponto de vista dos iniciantes, a barreira comercial precisava ser removida; transformá-la em uma tarifa ou em uma quota estava fora de cogitação. Por outro lado, como os iniciantes estavam de mãos atadas depois de submeter a disputa, tudo que eles podiam fazer era reagir de maneira a otimizar a resposta aos movimentos dos EUA (PORGES, 2003). No contexto do caso camarão-tartaruga, a decisão do órgão de apelação representa um resultado em que a disputa segue toda a tramitação do procedimento adjudicatório na OMC até que uma decisão final seja promulgada.

\section{Conclusão}

Neste artigo, passei em revista todos os resultados possíveis de disputas comerciais na OMC e relacionei esses resultados ao jogo de magnanimidade genérico, especificado no âmbito da teoria dos mo- 


\section{Disputas Comerciais e Magnanimidade: Um}

Estudo do Mecanismo de Solução...

vimentos. O Jogo de Magnanimidade contempla doze jogos de conflito, em que, por vezes, a ação magnânima é racional para um dos jogadores, fazendo com que esse jogador abandone o melhor resultado no jogo e busque o segundo melhor resultado, a fim de garantir uma resolução sustentável da disputa. Argumenta-se que a atitude magnânima é a principal explicação para a predominância de soluções amigáveis e soluções amigáveis qualificadas no âmbito das disputas comerciais protocoladas junto à OMC. Dois estudos de caso ilustram instâncias de solução amigável e solução amigável qualificada, assim como o papel da ação magnânima na facilitação desses resultados.

Também analisamos uma terceira categoria de resultados de disputas na OMC. Em retrospectiva, uma comparação entre o caso camarão-tartaruga e o caso do peixe-espada revela o papel que a jurisprudência desempenhou na hierarquia de preferências das partes no que tange à possibilidade de uma solução amigável. No caso do peixe-espada, que foi submetido quase dois anos após a decisão final sobre camarão-tartaruga, o receio de uma decisão a favor do meio ambiente no âmbito da OMC fez com que a UE buscasse uma solução amigável, antes mesmo da decisão do painel.

Essa explicação estratégica do comportamento das partes em uma disputa na OMC somente é possível quando se introduz a noção de equilíbrio não-míope no modelo. A capacidade explicativa da teoria dos movimentos no contexto destas disputas comerciais é extraordinária. De fato, a teoria dos jogos tradicional é muito limitada quando se trata de confrontar a tradição de soluções amigáveis na OMC. Uma abordagem mais próxima da realidade do comportamento racional dos países é necessária, e a teoria dos movimentos presta-se muito naturalmente a esta tarefa. 


\section{Notas}

1. Esta aplicação da TOM para analisar uma negociação multilateral se debruça sobre as preferências de três atores: o Japão, os Estados Unidos e a União Européia. Cada um dos atores tem uma posição distinta no que diz respeito a subsídios agrícolas e restrições a exportações, culminando com um acordo.

2. Por exemplo, a liberalização do comércio com a China tem sido associada a questões de proteção aos direitos humanos. Da mesma forma, a admissão da China à OMC em 2001, e posteriormente de Taiwan em 2002, foi negociada juntamente com outras questões, como segurança e ajuda internacional. Neste artigo, apenas as condições inerentes ao espaço adjudicatório da OMC que impactam as escolhas das partes serão levadas em consideração, muito embora as conseqüências desses casos para além do sistema da OMC sejam reconhecidas. Uma abordagem detalhada do impacto de payoffs e side-payments em negociações internacionais, por meio da formação de coalizões, pode ser encontrada em Oliveira et al. (2007, p. 26).

3. Reinhardt (2001) prevê outras oportunidades para uma solução amigável: a primeira, depois da formação do painel de peritos, mas antes da sua decisão; a segunda, depois que o orgão de apelação toma a sua decisão, mas antes que a mesma se torne pública.

4. Seguindo a mesma metodologia adotada para o número total de casos em análise, foram excluídas desta categoria três decisões do painel de peritos publicadas em 2006.

5. Reinhardt (2001) observa um viés a favor do proponente da ordem de 4 para 1 no âmbito do sistema do GATT (BUSCH; REINHARDT, 2002, p. 17). Já na OMC, este viés cresceu: 64\% das decisões de primeira instância proferidas até 2002 favoreceram o proponente (BUSCH; REINHARDT, 2003, p. 724).

6. Nessas circunstâncias, o proponente arca com os custos associados com o desenho e a implementação da medida retaliatória sobre segmentos da indústria exportadora do outro país. Medidas retaliatórias também podem afetar os custos das importações no mercado doméstico do proponente, o que representa ainda outra fonte de custos.

7. Custos relacionados ao enfraquecimento do sistema como um todo, diante do descumprimento de decisões no âmbito do MSC, tambem são possíveis. Sobre esse aspecto, ver Varella e Silva (2006, p. 34).

8. Um equilíbrio é classificado como Pareto ótimo quando nao for possível aumentar a recompensa de um dos jogadores sem que, simultaneamente, a re- 


\section{Disputas Comerciais e Magnanimidade: Um Estudo do Mecanismo de Solução...}

compensa do segundo jogador seja reduzida. Equilíbrios subparetianos são aqueles que não atendem às características de Pareto otimização. Ver Tsebelis (1990, p. 65).

9. Esta e as demais citações de originais em língua estrangeira foram livremente traduzidas para este artigo.

10. O termo solução amigável está sendo usado a fim de guardar proximidade com a distinção que existe na terminologia jurídica anglo-saxã entre settlement e friendly settlement. Enquanto o primeiro ocorre na esfera judicial e tem poder vinculante, o segundo acontece na esfera extrajudicial e pode ser objeto de revisão judicial.

11. A ordem de preferências proposta baseia-se no fato de que o MSC favorece o iniciante, bem como na existência de um viés na jurisprudência da OMC a favor do iniciante (REINHARDT, 2001; BUSCH; REINHARDT, 2002, p. 17; 2003, p. 724).

12. Existe ainda um conjunto de disputas que não se enquadra em nenhuma das categorias propostas; entre essas disputas, encontram-se casos que a OMC classifica como active panel, panel established e panel report circulated (o que significa que a decisão circulou entre as partes, mas ainda nao foi confirmada).

13. Apesar dos jogos de classe 1 e 2 compreenderem quatro jogos distintos em cada categoria, os dados disponíveis na OMC somente permitem uma aproximação do jogo de fato jogado.

14. Para uma abordagem exaustiva dos conflitos entre o direito internacional econômico e o direito ambiental, ver Dunoff (1994).

15. Em ambos os casos, o sistema do GATT/OMC abraçou a noção de barreiras comerciais extraterritoriais que tinham por objetivo a preservação de recursos escassos; entretanto, os casos foram decididos a favor do iniciante porque as respectivas barreiras comerciais haviam sido implementadas de maneira inconsistente com os acordos da OMC.

16. É importante ressaltar a história econômica recente do Chile, como exemplo de política de liberalização comercial.

17. A Seção 301 tem sido criticada pela literatura, como instrumento de aggressive unilateralism por parte dos EUA (BHAGWATI; PATRICK, 1991). Argumenta-se que o grande acordo que os EUA negociaram durante a Rodada Uruguai dizia respeito a restrições no uso da Seção 301 (WTO, 1999).

18. Ver o artigo XXIII do Acordo sobre Regras e Procedimentos que Regem a Solução de Controvérsias (WTO, 1994). 
19. Eu utilizo o modelo teórico proposto por Bueno de Mesquita et al. (2003) para agrupar as disputas comerciais na OMC em duas categorias: (i) disputas que têm por objeto bens públicos e (ii) disputas que têm por objeto bens privados. Os custos associados com uma decisão adversa são influenciados pela natureza do objeto da disputa. Via de regra, disputas sobre bens públicos acarretam custos menores, porque a percepção da perda ocorre de maneira difusa.

20. A lista dos países que requereram status de partes interessadas incluía: Brasil, Camarões, Canadá, Colômbia, Costa Rica, Cuba, Dominica, República Dominicana, Equador, Hong Kong (China), Índia, Israel, Jamaica, Japão, Coréia, Santa Lúcia e Tailândia.

21. Um segundo aspecto muito importante no caso camarão-tartaruga foi a oportunidade de participação da sociedade civil, por meio de organizações não governamentais (ONGs). Dunoff (1998) e Sanchez (2006) trazem uma abordagem detalhada dos mecanismos de participação previstos na OMC. Ver também Oliveira (2007, p. 18-21) para uma discussão do papel da sociedade civil no contencioso entre Brasil e Estados Unidos no que diz respeito ao caso das patentes.

\section{Referências Bibliográficas}

BHAGWATI, Jagdish; PATRICK, Hugh T. Aggressive unilateralism: America's 301 trade policy and the world trading system. Ann Arbor: University of Michigan Press, 1991.

BRAMS, Steven. Theory of moves. New York: Cambridge University Press, 1994.

BUENO DE MESQUITA, Bruce; SMITH, Alastair; SIVERSON, Randolph; MORROW, James. The logic of political survival. Cambridge: MIT Press, 2003.

BUSCH, Marc; REINHARDT, Eric. Testing international trade law: empirical studies of GATT/WTO dispute settlement. In: KENNEDY, D. L. M.; SOUTHWICK, J. (Ed.). The political economy of international trade law: essays in honor of Robert E. Hudec. New York: Cambrige Univeristy Press, 2002. 
Disputas Comerciais e Magnanimidade: Um

Estudo do Mecanismo de Solução...

Developing countries and general agreement on tariffs and trade/world trade organization dispute settlement. Journal of World Trade, v. 37, n. 4, p. 719-735, 2003.

DUNOFF, Jeffrey L. Institutional misfits: the GATT, the ICJ \& trade-environment disputes. Michigan Journal of International Law, v. 15, Summer, 1994.

The misguided debate over NGO participation at the WTO. Journal of International Economic Law, v. 1, n. 3, p. 433-456, Sept. 1998.

GUZMAN, Andrew; SIMMONS, Beth A. To settle or empanel? An empirical analysis of litigation and settlement at the World Trade Organization. Journal of Legal Studies, v. 31, n. 1, parte 2, p. 205-235, 2002.

HOWSE, Robert. The appellate body ruling in the Shrimp/Turtle case: a new legal baseline for the trade and environment debate. Columbia Journal of Environmental Law, v. 27, n. 2, p. 489-519, 2002.

HUDEC, Robert. Enforcing international trade law: the evolution of the modern GATT legal system. Salem: Butterworth Legal Publishers, 1993.

JACKSON, John H. The jurisprudence of GATT and the WTO. New York: Cambridge University Press, 2000.

KREPS, David M. Game theory and economic modeling. Oxford: Clarendon Press, 1990.

LEITNER, Kara; LESTER, Simon. WTO dispute settlement 1995-2006: a statistical analysis. Journal of International Economic Law, v. 10, n. 1, p. 165-179, 2007.

OLIVEIRA, Amâncio J. N. de; ONUKI, Janina; OLIVEIRA, Emmanuel de. Coalizões Sul-Sul e multilateralismo: Índia, Brasil e África do Sul. In: OLIVEIRA, A. J. N. de; ONUKI, J. (Org.). Coalizões Sul-Sul e as negociações internacionais. São Paulo: Mídia Alternativa Editora, 2007.

OLIVEIRA, Marcelo F. Multilateralismo, democracia e política externa no Brasil: contenciosos das patentes e do algodão na Organização Mundial do Comércio (OMC). Contexto Internacional, v. 29, n. 1, 2007.

PORGES, Amelia. Settling WTO disputes: what do litigation models tell us? Ohio State Journal on Dispute Resolution, v. 19, p. 141-184, 2003. 
REINHARDT, Eric. Adjudication without enforcement in GATT disputes. Journal of Conflict Resolution, v. 45, n. 2, p. 174-195, 2001.

ROSENDORFF, B. P. Stability and rigidity: politics and design of the WTO's dispute settlement procedure. American Political Science Review, v. 99, n. 3, p. $389-400,2005$.

SANCHEZ, Michelle R. Brief observations on the mechanisms for NGO participation in the WTO. Sur, v. 1, 2006.

SHAMSEY, J. ITLOS vs. Goliath: the international tribunal for the law of the sea stands tall with the appellate body in the Chilean-EU swordfish dispute. Transnational Law \& Contemporary Problems, v. 12, n. 2, p. 513-540, 2002.

STEGER, Debra P. Peace through trade: building the World Trade Organization. London: Cameron May Ltd, 2004.

TSEBELIS, George. Nested games: rational choice in comparative politics. Los Angeles: California University Press, 1990.

UNITED NATIONS. Division for Ocean Affairs and the Law of the Sea, Office of Legal Affairs. United Nations convention on the law of the sea of 10 December 1982. 10 Dec. 1982. Disponível em: <http://www.un.org/Depts/los/convention_ agreements/texts/unclos/closindx.htm>. Acesso em: 17 dez. 2008.

VARELLA, Marcelo Dias; SILVA, Alice Rocha da. A mudança de orientação da lógica de solução das controvérsias econômicas internacionais. Revista Brasileira de Política Internacional, v. 49, n. 2, 2006.

WTO - World Trade Organization. The General Agreement on Tariffs and Trade (GATT). 1947. Disponível em: <http://www.wto.org/english/docs_e/ legal_e/gatt47_01_e.htm>. Acesso em: 22 dez. 2008.

Understanding on rules and procedures governing the settlement of disputes. 1994. Disponível em: <http://www.wto.org/english/docs_e/legal_e/ 28-dsu_e.htm>. Acesso em: 22 dez. 2008.

United States - import prohibition of certain shrimp and shrimp products. WT/DS58/AB/R, 12 Oct. 1998. Disponível em: <http://www.sice.oas.org/ DISPUTE/wto/58abr.asp>. Acesso em: 17 dez. 2008. 
Disputas Comerciais e Magnanimidade: Um

Estudo do Mecanismo de Solução...

United States - sections 301-310 of the Trade Act of 1974. WT/DS152/R, 22 Dec. 1999. Disponível em: <http://www.sice.oas.org/DISPUTE/wto/tract01e.asp>. Acesso em: 17 dez. 2008.

Resumo

\section{Disputas Comerciais e Magnanimidade: Um Estudo do Mecanismo de Solução de Controvérsias da Organização Mundial de Comércio à Luz da Teoria dos Movimentos}

Por que disputas comerciais no âmbito da Organização Mundial de Comércio (OMC) são decididas predominantemente de forma amigável, não obstante a existência de um sofisticado mecanismo quasi-adjudicatório para a resolução dessas controvérsias? Como explicar a preferência da parte que inicia uma disputa pela solução amigável, quando se sabe que a OMC, em média, decide $64 \%$ dos casos a favor do iniciante? Este artigo analisa padrões de solução de controvérsias no sistema do Acordo Geral de Tarifas e Comércio e da Organização Mundial de Comércio (GATT/OMC), por meio da teoria dos movimentos (BRAMS, 1994), com o propósito de estudar as escolhas estratégicas disponíveis para as partes. Propõe-se que, no sistema do GATT/OMC, as partes em uma disputa comercial agem de forma magnânima quando abrem mão do melhor resultado em um jogo. Esta ação é racional porque ela oferece à parte demandada maiores chances de se alcançar uma solução amigável da disputa. Esse comportamento não encontra explicação satisfatória no conceito de equilíbrio míope da teoria dos jogos tradicional. Em contrapartida, a teoria dos movimentos incorpora a noção de equilíbrio não-míope ao seu modelo de tomada de decisões. Este artigo explica o comportamento não-míope e racional dos jogadores quando estes buscam o segundo melhor resultado no jogo. Três disputas comerciais ilustram a análise e caracterizam situações em que: (i) a solução amigável advém do comportamento magnânimo; (ii) a solução amigável ocorre a despeito do comportamento magnânimo; e (iii) não há solução amigável.

Palavras-chave: Teoria dos Movimentos - Organização Mundial do Comércio - Disputas Comerciais - Solução de Controvérsias - Magnanimidade - Equilíbrio não-Míope 


\section{Abstract}

\section{Magnanimity and WTO Disputes: An Examination of Early Settlement in Trade Disputes Using Theory of Moves}

Why most trade disputes in the World Trade Organization (WTO) end in a friendly settlement, despite the existence of a sophisticated dispute settlement mechanism? How can we explain the complainant's preference for a friendly settlement when we know that the WTO decides $64 \%$ of the cases in favor of the complainant? In this article I discuss patterns of settlement in the GATT/WTO system using theory of moves (BRAMS, 1994) to study the strategic choices available to disputants. I suggest that in the WTO system complainants act magnanimously, thereby bypassing their best outcome in a game. This is rational on their part because it offers defendants more opportunity to settle, which is beneficial to both sides. This behavior is not well explained by the myopic equilibrium concepts of standard game theory. By contrast, theory of moves incorporates non-myopic reasoning into its model of decision-making. In particular, I explain why it is rational for players to act non-myopically on occasion and move to their second-best outcome in a game. Three case studies illustrate the analysis (i) when settlement follows magnanimity, (ii) when settlement occurs regardless of magnanimity, and (iii) when there is no settlement. These three outcomes exhaust the empirical record of WTO disputes.

Keywords: Theory of Moves - World Trade Organization - Trade Disputes - Alternative Dispute Resolution - Magnanimity - Myopic Equilibrium 